\title{
Hochbruck, Wolfgang
}

\section{Living history as an educational tool and method in North America and Germany}

Zumhof, Tim [Hrsg.]; Johnson, Nicholas K. [Hrsg.]: Show, don't tell. Education and historical representations on stage and screen in Germany and the USA. Bad Heilbrunn : Verlag Julius Klinkhardt 2020, S. 81-97. - (Studien zur Deutsch-Amerikanischen Bildungsgeschichte / Studies in German-American Educational History)

Quellenangabe/ Reference:

Hochbruck, Wolfgang: Living history as an educational tool and method in North America and Germany In: Zumhof, Tim [Hrsg.]; Johnson, Nicholas K. [Hrsg.]: Show, don't tell. Education and historical representations on stage and screen in Germany and the USA. Bad Heilbrunn : Verlag Julius Klinkhardt 2020, S. 81-97 - URN: urn:nbn:de:0111-pedocs-205120 - DOI: 10.25656/01:20512

https://nbn-resolving.org/urn:nbn:de:0111-pedocs-205120

https://doi.org/10.25656/01:20512

in Kooperation mit / in cooperation with:

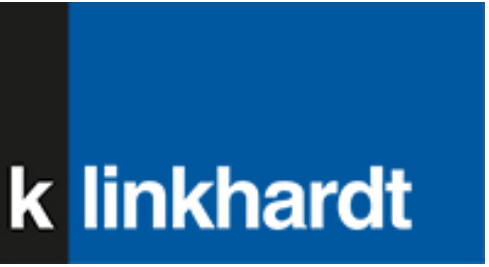

http://www.klinkhardt.de

\section{Nutzungsbedingungen}

Dieses Dokument steht unter folgender Creative Commons-Lizenz: http://creativecommons.org/licenses/by-nc-sa/4.0/deed.de - Sie dürfen das Werk bzw. den Inhalt unter folgenden Bedingungen vervielfältigen, verbreiten und öffentlich zugänglich machen sowie Abwandlungen und Bearbeitungen des Werkes bzw. Inhaltes anfertigen: Sie müssen den Namen des Autors/Rechteinhabers in der von ihm festgelegten Weise nennen. Dieses Werk bzw, der Inhalt darf nicht für kommerzielle Zwecke verwendet werden. Die neu entstandenen Werke bzw. Inhalte dürfen nur unter Verwendung von Lizenzbedingungen weitergegeben werden, die mit denen dieses Lizenzvertrages identisch oder vergleichbar sind.

Mit der Verwendung dieses Dokuments erkennen Sie die Nutzungsbedingungen an.

\section{Terms of use}

This document is published under following Creative Commons-License: http://creativecommons.org/licenses/by-nc-sa/4.0/deed.en - You may copy, distribute and transmit, adapt or exhibit the work in the public and alter, transform or change this work as long as you attribute the work in the manner specified by the author or licensor. You are not allowed to make commercial use of the work. If you alter, transform, or change this work in any way, you may distribute the resulting work only under this or a comparable license.

By using this particular document, you accept the above-stated conditions of use.

\section{Kontakt / Contact:}

\section{peDOCs}

DIPF | Leibniz-Institut für Bildungsforschung und Bildungsinformation Informationszentrum (IZ) Bildung

E-Mail: pedocs@dipf.de

Internet: www.pedocs.de

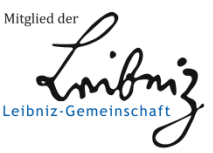




\section{Studien zur Deutsch-Amerikanischen}

Bildungsgeschichte / Studies in German-American Educational History

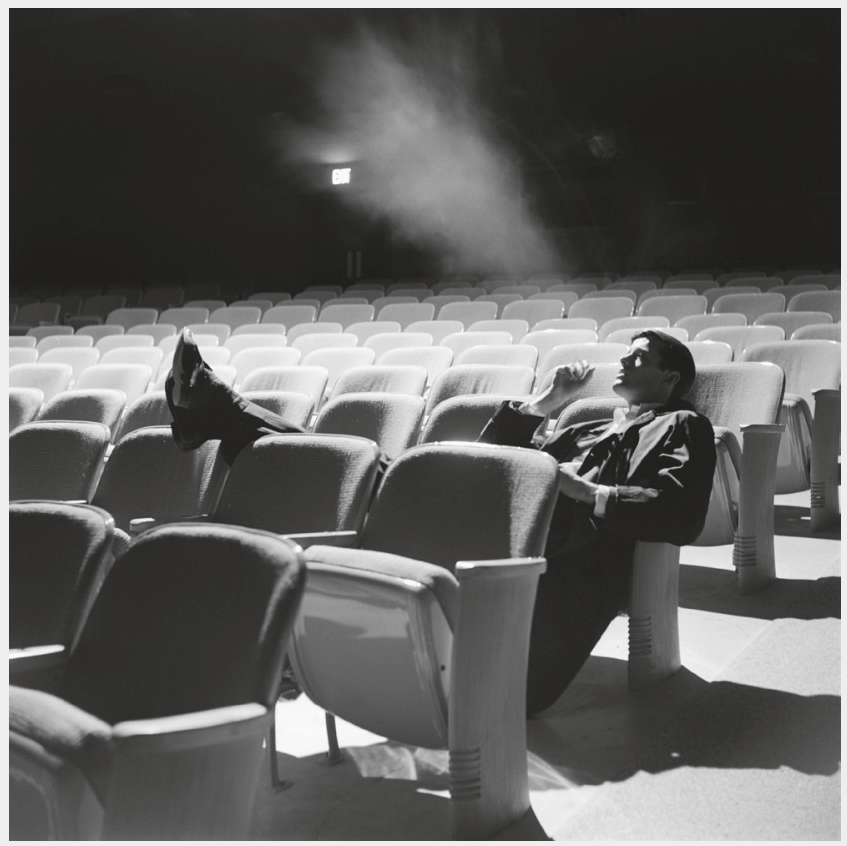

Tim Zumhof

Nicholas K. Johnson (eds.)

Show, Don't Tell

Education and Historical Representations on Stage and Screen in Germany and the USA 


\section{Zumhof / Johnson Show, Don't Tell}


Studien zur Deutsch-Amerikanischen Bildungsgeschichte Studies in German-American Educational History

General Editor Jürgen Overhoff 


\section{Tim Zumhof \\ Nicholas K. Johnson (eds.)}

\section{Show, Don't Tell}

Education and Historical Representations on Stage and Screen in Germany and the USA 
This volume was published in cooperation with the Center for German-American Educational History at the University of Münster.

Titel entstand in Kooperation mit der „Arbeitsstelle für Deutsch-Amerikanische Bildungsgeschichte".

\section{Arbeitsstelle für Deutsch-Amerikanische Bildungsgeschichte}

Dieser Titel wurde in das Programm des Verlages mittels eines Peer-Review-Verfahrens aufgenommen. Für weitere Informationen siehe www.klinkhardt.de.

Bibliografische Information der Deutschen Nationalbibliothek

Die Deutsche Nationalbibliothek verzeichnet diese Publikation in der Deutschen Nationalbibliografie; detaillierte bibliografische Daten sind im Internet abrufbar über http://dnb.d-nb.de.

2020.lg. (C) by Julius Klinkhardt.

Bildnachweis Umschlagseite 1: (C) Francis Miller (1961). Peter Fonda in theater audience seats at Omaha Nebraska Community Playhouse. The LIFE Picture Collection via Getty Images. - The cover photo is used for illustrative purposes only and does not represent an endorsement by the Peter Fonda estate.

Druck und Bindung: AZ Druck und Datentechnik, Kempten.

Printed in Germany 2020.

Gedruckt auf chlorfrei gebleichtem alterungsbeständigem Papier.

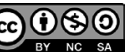

Die Publikation (mit Ausnahme aller Fotos, Grafiken und Abbildungen) ist veröffent-

licht unter der Creative Commons-Lizenz: CC BY-NC-SA 4.0 International

https://creativecommons.org/licenses/by-nc-sa/4.0/

ISBN 978-3-7815-5828-1 Digital

doi.org/10.35468/5828

ISBN 978-3-7815-2397-5 Print 


\section{Table of Contents}

Nicholas K. Johnson and Tim Zumhof

"Are you not entertained?" -

Education, Entertainment, and Historical Representations

on Stage and Screen in Germany and the USA, an Introduction .7

Tim Zumbof

Historical Culture, Public History, and Education

in Germany and the United States of America.

A Comparative Introduction to Basic Concepts and Fields of Research.

Jürgen Overhoff

"Geschichte ist etwas Fließendes."

Lion Feuchtwanger's Changing Understanding of History

and the Role of the Stage: From his Earliest Theatrical Productions

to his Play Waffen für Amerika (1943/44)

Simon Richter

Duell an der Havel:

Fritz von Unruh's Depiction of Eighteenth-Century

Prussian-American Relations

Alissa Rubinstein

The 614th Commandment:

A Documentary Play about how American Jews Feel

about Germany Today

Wolfgang Hochbruck

Living History as an Educational Tool and Method

in North America and Germany

Stephanie Johns

Theatre, Education, and Public History:

Teaching History at the Stratford Festival 
6 Table of Contents

Felix Apel

Hollywood's Influence on the Transmission of Historical Images:

Lars Kraumes' Der Staat gegen Fritz Bauer

Thorsten Carstensen

Learning from John Ford:

History, Geography, and Epic Storytelling in the Works of Peter Handke

Raymond Haberski, Jr.

The Passion of Richard Schickel: What We Expect from War Films

160

Nicholas K. Johnson

"A classroom history lesson is not going to work":

HBO's Conspiracy and Depicting Holocaust Perpetrators on Film

Table of Figures

List of Contributors

Index

Acknowledgements 


\section{Wolfgang Hochbruck}

\section{Living History as an Educational Tool and Method in North America and Germany}

"I'm doing this to educate people"1 is a statement often heard from costumed participants doubling as self-appointed historians, speaking to the audience on the sidelines of so-called reenactments. This form of open-air history theater enjoys the most popularity in the US, but increasingly also in other parts of the world. Usually, the reenacted event is of a military nature, and in the US that means more often than not a battle from the American Civil War (1861-1865). This does not imply that the two- to three-day event necessarily takes place anywhere near an original battlefield or skirmish site: Civil War battle reenactments may be encountered in any one of the fifty States of the Union. Most frequently, they are hosted in the formerly slave-holding South, where they are part of a plethora of attempts at upholding a positive if reactionary image of the secessionist Confederacy. And they can be encountered in France, Great Britain, New Zealand ... and Germany. Theatrical re-plays of history are not only not limited to original sites; they are not even bound to the original country, or world region. There are reenactments of the First World War in North America, just as there are Operation Market Garden (which took place in the Netherlands in 1944) reenactments in Australia. The differences are most visible in the numbers of attendees: Obviously, the $135^{\text {th }}$ anniversary reenactment of the battle of Shiloh in Tennessee will draw more participants and spectators (there were roughly 10,000 active players in April 1997) than a more-or-less generic scenario outside of Davenport, Iowa, where there never was a battle, historically. Or, for that matter, a similarly generic scenario on the military training site near Külsheim in the romantic valley of the Tauber in Southern Germany. One stable factor throughout, regardless of numbers in attendance, period in question, or event format, however, is this: There has rarely been this much history in the sense that so many people from such diverse backgrounds actively participated in its construction. This appears to signal democratization, but the signal is not the message: Current developments in some countries of the European community, including Germany, and especially in the US, indicate that nationalist and illiberal populist movements use formally democratic methods to

1 Alan Archambault. "Reflections on Civil War Reenacting." Camp Chase Gazette 21.5 (1994): 3435. - The author is grateful to Kübra Aydin and Christina Metzger for editorial assistance and suggestions in the process of preparing this paper for publication. All remaining mistakes and incongruencies are of course the responsibility of the author. 
imbalance, and undermine, the very democracies that these countries' political systems are based on. A lot of the impact of these illiberal forces depends on positions towards, and knowledge of, history. The future of liberal democracies thus depends to a large extent on whether responsible forces within the educational system(s) - university, schools, and museums alike - are willing to make use of all the possibilities and opportunities at their disposal.

The alternatives are not exactly inviting. The leveling of cultural hierarchies that appears to be happening with the takeover of historiography by other means in the reenactment scene does not necessarily entail progressive views on the side of the actors. Not that there is always an evil conspiracy behind reactionary messages: Reenactment communities rely to a large extent on older, accessible, and popular historiography. Only a minority has the time and/or the means to stay abreast of current research - and those that do are unfortunately more often than not shunned by professional historians. And then there are the regressive fringes, the "you won't find this in the history books, but..." - types. Their fringe publications are far easier to avoid than their vociferous presence on the "battlefields" where they constitute a clear and present danger, especially when encountered by unsuspecting and receptive members of the public.

In the following, I shall try to elucidate some of the limitations and possibilities that the living history method, and especially live action role play/reenactments (LARP), offer for public education systems. That reenactments, "documentary" living history formats on TV, retro-fashions of all kinds, and even historical pageantry have taken on sizable proportions in everyday life and even more so in non-everyday historical anniversary festivities is not an issue that needs to be debated: The many and diverse theatrical presentations of history are here to stay. The reluctance of establishment historiography, including the school systems, to engage with living history methods is, to a certain extent, both natural and understandable. There is no living history. There are only varieties of re-constructing pasts either along the lines of majority historiography, or in progressive or regressive adaptation formats. And of course, a lot of what passes for "reenactment" provides an easy target for critical historians, journalists, and self-appointed anti-militarists. The close isomorphy of some highly-dedicated groups and individuals, and their remarkable research levels, are usually ignored in favor of what even the untrained eye is able to detect in terms of historical inaccuracies: the camping coolers and furniture in camps, the cigarettes and non-period food, the modern haircuts and eyeglasses, and the hopelessly inadequate performances. Usually, these hobbyists are below the standard of what among reenactors is referred to as "mainstream" - all-year carnivalists who like battlefield-karaoke, and who often also follow simplistic political ideologies.

The gap between these recreators and the dedicated re-creators does not receive a lot of attention because serious journalists cannot gain much by trying to point 
out how, and why, active participation in a reenactment might provide a basis for a better understanding of history when it is so much easier for them to shoot fish in a barrel. Besides, whereas everything and anything from the Stone Age to the Vietnam War can be reenacted in the US, there are only few historical periods that are uncontroversial in Germany. The most acceptable period representations are Roman, having been collectively authenticated by Markus Junkelmann's experimental archaeology expeditions ${ }^{2}$, and, somewhat surprisingly, the so-called "medieval markets" - fun-fairs with music, shows, and food. Surprisingly, since the supposed darkness of the "dark" middle ages was largely one of aristocratic and clerical oppression and dumbing-down of large parts of the population by an oligarchic minority - school-knowledge about which does not seem to have made a dent into the German preference for knights and their ladies. While Americans have their Civil War, during the Germanic romantic and imperial periods, ${ }^{3}$ the hegemonial forces established a reverential frame complete with veneration for spectacular ruins, ghosts, and aristocratic heroes, which continued in the school system deep into the 1970s and partly to this day, because it is still supported by a wave of musealization, monumentalization, and historic pageantry reaching back into the nineteenth century. Given this situation, it does not come as much of a surprise that there is next to no knowledge about German participation in the American Civil War, where more than 200,000 German-born men (and many women) worked and fought to preserve the Union and to abolish slavery. Not only that: a significant number of survivors and refugees of the failed revolutions of 1848/49 turned up again in the Union forces, often in leadership positions. And there was a disproportionally high number of Germans among the mostly white officers of the US Colored Troops (USCT), recruited from former slaves and free African-Americans from 1862 onwards. This is a chapter of German democratic and anti-racist history which happened elsewhere, but which can be made useful as a source of identification for youth looking for role models. Heroism and role models are on many state education plans (Bildungspläne) for the eighth grade, when students do not like to read a lot but love to see action.

Now if military pageantry and reenactments are not as popular in Germany as they continue to be in the US and other countries, there are of course substantial $20^{\text {th }}$ century historical reasons for this reluctance. A plus-size battle-reenactment performed within the framework and as an official part of a national festivity like

2 Marcus Junkelmann. Die Legionen des Augustus: Der römische Soldat im archäologischen Experiment (Mainz: Zabern, 1986).

3 Wolfgang Hochbruck. "Chronosyndrom Light: Mittelalter als Projektions- und Rückzugsraum," in Das Mittelalter zwischen Vorstellung und Wirklichkeit. Probleme, Perspektiven und Anstöße für die Unterrichtspraxis, ed. by Thomas Martin Buck and Nicola Brauch (Münster: Waxmann, 2011), 217-233. 
the 2012 Borodino reenactment in Russia ${ }^{4}$ would be unthinkable, as are public battle festivities like the Gettysburg reenactment of 1998, with its unsurpassed 30,000 active participants. The closest Germans have come so far to anything of the kind was the privately-organized 2013 spectacle in Leipzig celebrating a decisive victory of the Napoleonic period.

Unfortunately, a sort of counter-reenactment organized by the artist Bertram Haude attracted too few participants and disintegrated before they reached the scene, but it left at least an idea of how to deal with the lack of reflection that usually fuels the problematic aspects of the battle-reenactment format. ${ }^{5}$ It also indicated how live action role play as history theater can be used as a didactic tool for positive reflection and pro-democratic purposes, because Haude and his little band did exactly what the other reenactors were doing - only they selected a different, less documented and less frequently thematized segment from the historical past: the plight of the sick and the wounded, and the hunger and the misery in the wake of glorious victories as well as defeats. The bandwidth and variety of methods of living history is larger, and more diverse, than the celebratory militarism of reactionary politics of history suggests.

Reenactments, as stated above, are an open type of live action role play and thus an internationally popular form of historical gaming. One main difference between historical reenactment and other branches of live action role play, such as fantasy LARP, is that reenactors do not usually adopt fantasy names, and that they strive for historic "authenticity". However, this exactly is already one of the main points of contention between the reenactment communities on the one side, and academic historians, many teachers, and similar numbers of museum curators on the other. Whereas LARP and other forms of enacted fantasy fiction focus on the gamer crowd and on personal experience, one of the persistent (and in fact founding) myths about reenactments is that they are objective attempts at replicating their various target pasts.

The question frequently left open at this point is whose history is being reenacted, by whom, and why, or rather with what kind of outcome in mind. Since performance is a form of narrative and cannot be equivocating, the idea voiced by many in the field - that reenactments are not political - may as well be discounted as a political myth.

The origins of this myth lie not in insidious attempts at camouflaging political agenda, but in the popularity and acceptance of the other two main formats of "presenting" the past, experimental archaeology, and the more traditional forms of

4 Regine Nohejl. "Ruhm dir auf ewig, Borodino! Der Vaterländische Krieg im Russland der Gegenwart." Osteuropa 63.1 (2013): 61-74.

5 Bertram Haude. "Krieg als Hobby? Das Leipziger Völkerschlacht-Reenactment und der Versuch einer Entgegnung." Forum Kritische Archäologie 4 (2015): 1-12. 
living history interpretation in (open-air) museums. The terminological triad can be traced to Jay Anderson, ${ }^{6}$ whose article about the three main formats of history theater also introduced the expression "living history" into public discourse. At the time, the didactic practice of what was thought of as living history programs in most open-air museums was largely limited to pockets of historical practices, i.e. older, often retired skilled craftspersons showing their trade to audiences in designated areas, often a workshop transferred to the site complete with tools and patina. Popular trades were, and continue to be, those of weavers, blacksmiths, wheel- and cartwrights, broom-, basket-, and straw-shoemakers, and generally all those trades and their products of which can afterwards be sold in the museum store.

The popularity of experimental archaeology, with the sailing adventures of Thor Heyerdahl in the 1960s as a pivotal moment, added a grander scale to these clandestine operations. ${ }^{7}$ With the gradual disappearance of the historical manufacturing trades, a blacksmith using early $20^{\text {th }}$ century tools, and Harm Paulsen's construction and successful application of replicated objects that the bronze-age Ötztal glacier mummy carried ${ }^{8}$, become didactically and therewith cognitively almost equidistant for school classes and visitors. Their focus on the object level, and their result in a tangible product, or effect, hide both their embeddedness in a specific sociohistorical situation, and their nature as theatrical performances.

In the decades after 1960, German and American museums took different turns regarding this issue. In the US, the Civil War centenary precipitated an unprecedented surge in reenactment organisation and participation, whereas the acceptance of living history programs in Germany remained almost entirely limited to the individuals displaying their craft. ${ }^{9}$ Exceptions, because of their scientific underpinnings, were the endeavours of experimental archaeologists in the wake of historian Markus Junkelmann's traverse of the Alps on the trails of Roman legionaries. ${ }^{10}$ Consequently, reports and TV shows about experimental proof of the practical usability or applicability of tools and weaponry, or of trade and migration routes, reach as wide an audience as they do in the US. Also acceptable are historical documentaries on TV using (reen-)actors for scenes representing

6 Jay Anderson. "Living History: Simulating Everyday Life in Living Museums." American Quarterly 34 (1982): 290-306.

7 Ralling Christophe. Thor Heyerdahl: Eventyret og Livsverket (Oslo: Gyldendal Norsk Forlag, 1989).

8 Volker Arnold. "Laudatio zur Verleihung des 5. Deutschen Archäologiepreises der DGUF an Harm Paulsen." (laudatory speech given at 7. Deutscher Archäologiekongress, 3.-7. Oktober 2011, Bremen).

9 Eva Maria Brownawell. Die Amerikaner und ihr Krieg: Analyse der Jahrhundertfeier des Civil War in den Vereinigten Staaten von Amerika 1961-1965 (Stuttgart: Metzler, 1978).

10 Marcus Junkelmann. Muli Mariani: Marsch in römischer Legionärsrüstung über die Alpen (Stuttgart: Schriften des Limesmuseums Aalen, 1985). 
scenarios, or actions, as long as they bear in their shields the official stamp and mark of "documentary" and therefore supposed neutrality.

\section{Intentional History}

By comparison, reenactments are not neutral. They are a form of intentional history, even though participants may not be aware of it. It is true that at least as far as the higher quality groups and individuals are concerned, a lot of reenacting effort also goes into detailed attempts at isomorphic replication on the material level, and on which regiments were where at which moment of the day. This detailed knowledge is then presented as educational material, whereas the macrolevel is usually tacitly assumed to be shared knowledge between presenter and audience. However, this is exactly where the intentionality comes in: reenactments, especially battle reenactments, display agonality in a mutually reassuring format between actors and spectators. They recreate events as they supposedly happened, with the supposition largely remaining unquestioned in favor of a suggested agency on the side of participants. As re-enactments, they not only terminologically superscribe the original events with a narrative coherence, and often closure, that strips these events of their inherent contingencies and makes them retroactively enactments of the sense-making process that followed them. The majority of reenactments thus constitute attempts at conserving an increasingly unstable grip on a past as it was in the schoolbooks that the reenactors, their parents, and grandparents grew up with.

As a theatrical re-staging of past events, reenactments go far back. As educational tools in a wider sense, their use is almost as old. Originally, they were either religiously motivated and of a ceremonial nature, supposedly recreating an original belief-inspired event, or a direct godly intervention, or else they were propaganda performances for audiences separated from the original heroic deeds through time and space. From the Catholic Church and Napoleonic France, reenactments moved on to more secular cultural formations in the nineteenth century, when Civil War veterans reenacted themselves, and the Southern para-aristocracy and other aristocrats all over Europe dressed up as medieval characters inspired by Sir Walter Scott and other writers of historical novels. The difference from earlier recreational forms of medievalism during the reign of Emperor Maximilian and the Romantic age was that the $19^{\text {th }}$ century did not rely on the more fantastic chansons de geste as resources, but on historiography written by, and approved of by, the eminent historians of the period. Walter Scott's and James Fenimore Cooper's inscription of fictional characters into this researched history opened the floodgates for the reenactment of established historical factualities, with the reen- 
actors taking on the roles of historical characters. With the separation of time and space in the creation of romantic ruins (with their decay arrested, or even partially reversed), and then open-air folklore museums from the end of the nineteenth century, re-living pasts seemed to become a - pun unavoidable - recreational possibility.

Apart from some clubs, however, and pockets of historically-inspired partying, there was relatively little in the way of historical reenactments by ordinary citizens during the first half of the $20^{\text {th }}$ century. Costumed interpretation in museums likewise started slowly, faster in the US than elsewhere, with Freeman Tilden providing a first theoretical basis. ${ }^{11}$ However, and this is the decisive moment, these two forms of historical representation developed parallelly, and with interfacing margins: Some museums started their own (costumed) interpretation programs, other museums at least work with volunteers -- and those volunteers are often recruited from the ranks of local / regional reenactment groups.

By comparison, few German museums ever attempted to raise their own troupes (one exception is Kiekeberg near Hamburg ${ }^{12}$ ) of civilian farmers and artisans. A few cases initially looked promising, with historically fairly accurate theatrical programs in German museums offered and implemented by reenactment companies. However, the museum directors upon closer inquiry admitted that they had only cooperated with the reenactors in order to attract more visitors. ${ }^{13}$ Given that what they received were carefully scripted and staged scenarios, this covert disdain appears even more incomprehensible. And just when a more serious debate about the possibilities and ranges of high-quality living history programs in museums got under way after 2000, a paunchy "Germanic" reenactor openly displayed an SS-tattoo at a city fair accompanying a celebrated museum exhibition, which by and large terminated the discussion. At the same time, attempts at establishing independent quality management did not get off the ground due to lack of funding. The theoretical foundations were established in a series of museum workshops.

11 Freeman Tilden. Interpreting Our Heritage (Chapel Hill: University of Northern Carolina Press, 1957).

12 Heike Duisberg. "Gelebte Geschichte 1804: Ein Türöffner in die Vergangenheit. Das Freilichtmuseum am Kiekeberg," in Living History in Freilichtmuseen: Neue Wege der Geschichtsvermittlung, ed. by Heike Duisberg (Rosengarten-Ehestorf: Schriften des Freilichtmuseums am Kiekeberg, 2008), 60-78.

13 Michael Faber. "Living History - Lebendige Geschichte oder Geschichte (er)leben?: Möglichkeiten, Methoden und Grenzen am Beispiel des Rheinischen Freilichtmuseums Kommern," in Living History im Museum: Möglichkeiten und Grenzen einer populären Vermittlungsform, ed. by Jan Carstensen, Uwe Meiners, and Ruth-E. Mohrmann (Münster: Waxmann, 2008), 117-133. Cf. Uwe Meiners. "Verlebendigungsstrategien im Freilichtmuseum: Gedanken über Chancen und Probleme populärer Vermittlungsversuche," in Living History im Museum: Möglichkeiten und Grenzen einer populären Vermittlungsform, ed. by Jan Carstensen, Uwe Meiners, and Ruth-E. Mohrmann (Münster: Waxmann, 2008), 161-174. 


\section{Education for Citizenship}

What a progressive and positive approach to living history interpretation can do even without a lot of training, but with a coherent didactic concept, became visible in Offenburg / Baden in September 1997. On the occasion of the $150^{\text {th }}$ anniversary of a meeting of democrats in the vanguard of the revolutions of 1848/49, the city's manager of cultural affairs, Hans-Joachim Fliedner, convinced everybody from the city mayor to local sports clubs to celebrate in style. Burda, one of Germany's largest fashion publishers with their company seat in Offenburg, printed and provided historical sewing patterns. With 4,000 costumed participants, including reenactors and theater troupes, and more than 100,000 visitors, the Offenburger Freiheitsfest became the biggest, happiest, and most colorful living history party at least on the German record.

What can be done if professional training and scholarly reflection are available is visible from what the program directors in the Colonial Williamsburg, Virginia, restoration project call "Education for Citizenship". The partially restored $18^{\text {th }}$ century capital of the Commonwealth of Virginia has, over the course of almost a century, morphed from a reactionary celebration of white, Anglo-Saxon Protestant and predominantly male late-colonial culture to a critical yet constructive and educational view of every one of these hegemonial issues. Williamsburg has been in the vanguard of developments in the field of living history interpretation and museum theater for decades. ${ }^{14}$ Earlier than others, Williamsburg saw that just hiring aging practitioners of dying trades was going to lead into a literal dead end. They formed an education department and started apprenticing young people to their old blacksmiths, cartwrights, and printers. They were among the first to hire permanent staff for costumed interpretations and to develop coherent and comprehensive interpretation programs. They started breeding farm animals back to their eighteenth-century size and type. They started operating with first-person interpreters attempting to stay in character throughout the opening hours, and they were the first to rethink their insistence on the format when it became apparent that too many visitors had nothing better to do than to try and trip up the interpreters. Moreover, the limitations of a first-person approach - how many

14 On the topic, see Cary Carson. "Colonial Williamsburg and the Practice of Interpretive Planning in American History Museums." The Public Historian 20.3 (1998): 11-51; Richard Handler and Eric Gable. The New History in an Old Museum. Creating the Past at Colonial Williamsburg (Durham: Duke UP, 1997); Richard Handler, Eric Gable, and Anna Lawson. "On the Uses of Relativism: Fact, Conjecture, and Black and White Histories at Colonial Williamsburg." American Ethnologist 19.4 (1992): 791-805; Richard Handler and Eric Gable. "The Authority of Documents at Some American History Museums." The Journal of American History 81.1 (1994): 119136; Martine Teunissen. Representations of the Past in Public Spheres. Experiencing the Past: The Reconstruction and Recration of History at Colonial Williamsburg (Oegstgeest: Beleef Het Verleden, 2016). 
people really do have an understanding of their current cultural, social, and political situation, and can communicate it to visitors? - became overtly apparent and led to another overhaul of didactic methodologies. With the aid of leading European practitioners like Mark Wallis, they divided tasks and went beyond the mere interpretation of historical trades and places towards interlocking, week-long theatrical shows narrating the histories of Williamsburg, with special focus on the last years of the War of Independence.

Theatrical presentations of history in Williamsburg do not stop at reiterating well-known stories of Lord Dunsmore, Benedict Arnold, and General Cornwallis. They also tackle controversial topics like slavery, generating international headlines when they staged a slave-auction in the early 1990s. ${ }^{15}$ Consequently, they also desegregated their African-American interpretations. Now everybody can get into the role of a slave, a burgher citizen, a British soldier, or an American patriot. This last step is of particular importance. Most of the "posts-" in critical discourse upon closer inspection turn out to be little more than denials that the conditions to which they are supposed to be the "post-" persist. The living history programs at Williamsburg are aiming at a condition when actors and audiences can be unconcernedly quiet, and accepting, about issues of race: "authenticity" is not a question of skin color.

The learning effects are quite literally observable in the faces and physical demeanor of members of the audience. Seeing ethnic Caucasian, Asian, Hispanic and African interpreters perform together triggers visible reactions indicating that, and how, an ingrained yet subconscious view has been shaken.

Similarly, when a British loyalist is supposed to be tarred and feathered, the audience participation - invited and encouraged in a number of situations - is used as leverage when some costumed actors, carefully interspersed in the mob action, start interfering and ask whether the right to free speech was not one of the important aims of the American Revolution. It is very encouraging to see how quickly even the typical loud-mouthed, self-appointed patriots are deflated in this scene, often to the surprise of their children.

None of the currently operational German open-air museums with their strongly folklore-bound agenda has been able to follow suit. Whereas many of them do have what is called a museum pedagogy section, this rarely rises above and beyond skill-oriented programs for children, and school-classes, which is fair enough

15 On this controversial issue see Tamara Jones. "Living History of Undying Racism: Colonial Williamsburg 'Slave Auction' Draws Protest, Support.” African Diaspora Archaeology Newsletter. 1.3 (1994): 1-3; Scott Magelssen. "Making History in the Second Person: Post-touristic Considerations for Living History Interpretation.” Theatre Journal 58.2 (2006): 291-312; Scott Magelssen. Living History Museums: Undoing History Through Performance (Lanham MD: Scarecrow, 2007); Jason Stupp. "Slavery and the Theatre of History: Ritual Performance on the Auction Block." Theatre Journal 63.1 (2011): 61-84. 
considering the limited budgets, and the reluctance on the side of the museums to engage in political education. Consequently, programs engaging children in activities like painting with self-prepared colors, writing with quill and ink, or early medieval agriculture, flourish in Roman sites like Xanten and monasteries like Lorsch, but without conveying much of an insight into the political positions of the few who learned to read and write in, for instance, the Carolingian empire. The fear of propagating political messages via theatrical spectacle will also likely prevent the adoption of Williamsburg-like programs in one of the sites best-suited for the purpose, the Frankfurt Paulskirche, where the first national assembly of democratically elected delegates congregated in May of 1848. Not that political theater in German museums were without precedent altogether, though: It was another 1848 commemoration that experimented with hired actors for the $150^{\text {th }}$ anniversary of the failed revolution in Baden in Karlsruhe in the summer of 1998. ${ }^{16}$ The audience response was favorable enough, but the experiment ended when the exhibition closed, and has at least to my knowledge not been repeated elsewhere.

\section{Living History in Schools}

There is a slow but steady increase in the use of living history interpretation in both US and German schools. Which is somewhat surprising, since schools do not usually have a concrete local or chronotopical connection to whichever episode from history is supposed to be presented, and the theory of living history so far has been one of enlivening sites, rather than operating on its own. Reenactments, too, try to recreate "period" environments - if the original site of the medieval battle is now a supermarket parking lot, the reenactment moves to a mimicry site that will accommodate the karaoke battle.

The limits lie elsewhere. For one, it is difficult to establish anything approaching even the limited credibility of a re-enacted situation in a typical German or American school classroom. The problem is partly contained in what Samuel Taylor Coleridge called "the willing suspension of disbelief" - but that referred to the comparatively substantial illusionist capacities of the theater. Transforming a school classroom into a living history situation needs more effort, and not necessarily in the physical sense. The direction a living history classroom needs to take

16 Wolfgang G. Schmidt and Babette Steinkühler. "Schauspieler zeigen die Revolution 1848/49," in Inszenierte Geschichte(n), ed. by Badisches Landesmuseum, Andrea Altenburg (Baden-Baden: Nomos, 1999), 67-83. 
is the one Stephan Packard has called inventibility. ${ }^{17}$ Which refers to the capacity of, for instance, children, to combine figurines from Star Trek, medieval knights, and cowboys $\&$ Indians to new game arrangements. Inventibility is visible in A. A. Milne's Pooh Bear stories, and in Alice's Adventures in Wonderland. Inventibility steers the imaginative (rather than the fantastic) away from the conventional. Secondly, there are few if any training programs for interpreters, at least in mainland European countries. There has been a National Association for Interpretation in the US since 1988, with official training and certification programs, but of course not everybody who volunteers for a school program is a certified interpreter. There are numerous instances of reenactors just bringing and showing their gear, though the presence of even reenactors' guns is no longer encouraged by many American schools in the wake of recent school shootings. For the sake of "authenticity", a number of programs have therefore been abandoned. There have been few attempts at training teachers in the fine art of living history. ${ }^{18}$

Thirdly, while the use of drama and theater for teaching purposes is gaining ground in both the North American and German school systems, it is not always the same thing everywhere. It is true that as theatrical methods are adapted for classroom purposes, more and more subjects are becoming involved. What started as reading and interpreting drama in language and literature classrooms respectively has by now reached biology, and even mathematics. ${ }^{19}$ Yet while the beneficial effects of theater as a didactic method are generally acknowledged, teaching history through theater does not necessarily meet with unanimous approval, even from those who gathered at least experimental experience. Reservations are brought forward for a variety of reasons, two of which I already mentioned: doubts about the qualification of living historians/reenactors in the classroom, and the allegedly questionable relation of history taught through theater to what is considered a proper approach according to school history textbooks. ${ }^{20}$ The other critical categories are the overidentification of theater as a medium with predominantly aesthetic focus, and the tendency in the didactics of history, if they actually use living history as a

17 Stephan Packard. "The Inventibility of Other Audiences: Thoughts on the Popular Ideology of Fiction in Transnational Comic Books, on the Occasion of Captain Marvel \#1." IJOCA. International Journal of Comic Art 20.1 (2018): 65-81.

18 The author conducted a class on "History Theatre" in the Summer of 2018 at ALU Freiburg. A different course was taken by Vicky Middleswarth. "History and Hardtack: A Museum Workshop Program for Kentucky Teachers.” Journal of American Culture 12.2 (1989): 87-92. - This workshop had teachers outfitted and living in a reenactment setting. See also Julie A. Taylor. "Teaching African American History Through Museum Theatre." The Councilor: A Journal of the Social Studies 72.1 (2011): 1-11.

19 Martin Kramer. Schule ist Theater. Theatrale Methoden als Grundlage des Unterrichtens (Hohengehren: Schneider, 2013).

20 Elisabeth Hank. "Spiel im Geschichtsunterricht." Geschichte in Wissenschaft und Unterricht 42.4 (1991): 355-368. 
method, to re-stage ceremonies and rituals. ${ }^{21}$ This is possibly done to avoid personalizing, but of course ceremony and ritual follow rules that not only greatly differ from everyday life but rely on a code of signs and signals that is difficult to understand and fathom. Accordingly, some critics have noted that simple applications of role-play to what must have been rather complex scenarios even to contemporaries led to rather uneven results and even failure ${ }^{22}-$ not too difficult to imagine if the available roles and models are taken from collections like Hohmann. ${ }^{23}$ One model format that has in the past successfully brought together teachers, students, and living historians, was developed by the Southwest German Geschichtstheatergesellschaft in the wake of the $150^{\text {th }}$ anniversary celebrations of the revolutions of $1848 / 49$. The - intentional - aim was to draw attention to the fact that with the defeat at Rastatt and internment in Switzerland, the revolution maybe failed, but that it did not end. Most of the republican forces escaped to Switzerland, from where they dispersed to other countries. Many of those refugees later fought for the Union and against slavery in the American Civil War - which they helped win. Given the rather bleak image of German history of the first half of the twentieth century as a role model for students, The Second Fight for Liberty, as former Prussian officer and Forty-Eighter refugee Friedrich Anneke called a small book he published in 1861, holds a considerable appeal. With this in mind, the troupe performed a stage show of the same title on a variety of occasions, flanked by both popular and scholarly lectures, articles and radio interviews for local, regional, and national media, and a volume of essays. The effects were unanimously positive: even where students did not go along with the show, or professed to be interested only marginally, they admitted that they took home the message that here was something positive to report. That Germans successfully fought for liberty and human rights, even though the fighting had taken place in another country, was generally seen as encouraging.

The didactic innovation that resulted in a rethinking of educational strategies came about more or less accidentally. Preparing for the show at a school following a history workshop, it turned out that most of the troupe would not make it, and that the rest were scheduled to arrive only shortly before the scheduled presenta-

21 Tim Neu. "Vom Nachstellen zum Nacherleben: Vormoderne Ritualität im Geschichtsunterricht," in Echte Geschichte. Authentizitätsfiktionen in populären Geschichtskulturen, ed. by Eva Ulrike Pirker, Mark Rüdiger, Christa Klein, Thorsten Leiendecker, Carolyn Oesterle, Miriam Sénécheau, and Michiko Uike-Bormann (Bielefeld: transcript, 2010), 61-73.

22 Klaus-Ulrich Meier. "Rollenspiel," in Handbuch Methoden im Geschichtsunterricht, ed. by Ulrich Mayer, Hans-Jürgen Pandel, and Gerhard Schneider (Schwalbach: Wochenschau, 2007), 325-341. Brigitte Dehne. "Wie komme ich zum Rollenspiel? Ein Bericht aus der zweiten Ausbildungsphase." Geschichte Lernen 23 (1991): 92-95.

23 Franz Hohmann. Kurze Szenen und Rollenspiele für den Geschichtsunterricht (Bamberg: C.C. Buchner, 2008). 
tion. We ended up improvising with volunteers from the ranks of the students, trying out costumes, poses and texts. The effect was a reenactment version of Bertolt Brecht's concept of the "learning-play", Lehrstücktheater, with the students learning by acting out rather than witnessing specific situations - finding out what it does to a person to be forced into a subservient position, being pursued through a room by police, being issued a uniform and a rifle, and so on.

There were two factors setting this workshop and the staged event apart from Brecht, and from the show as it had been performed before. The major difference from the potentially Brechtian experience during a reenactment was the lack of immersion in the experience preceding and enabling the learning-play level of reflection ${ }^{24}$. The other was the mixing of students and group members. Most of the scenes are tabloid, forming up to, or breaking out of, a tableau stasis. Also, several of the scenes in the show are not ceremonial but allegorical in nature rather than even attempting to approximate real-life experiences. The students had gone along, even though we noticed that some were smiling at what to them must have looked like vaguely ridiculous pathos and were occasionally exchanging glances among themselves. This - entirely understandable - attitude changed quite literally dramatically the moment the other members of our group arrived. They had already dressed up, simply walked onto the stage in their grimy and well-worn campaign gear, and fell into positions they figured were adequate for the partly allegorical "Defense of the Republic" tableau (see Fig. 6). What students told us afterwards in the informal debriefing was that this had been a moment of shock and recognition. "And then it was like these guys had walked right out of history and joined us up here, and suddenly we were part of that history."

24 Wolfgang Hochbruck. "Between 'Living History' and Pageantry: Historical Reenactments in American Culture," in Beyond the Mainstream [Contemporary Drama in English 4], ed. by Peter-Paul Schnierer (Trier: wvt, 1997), 93-105. 


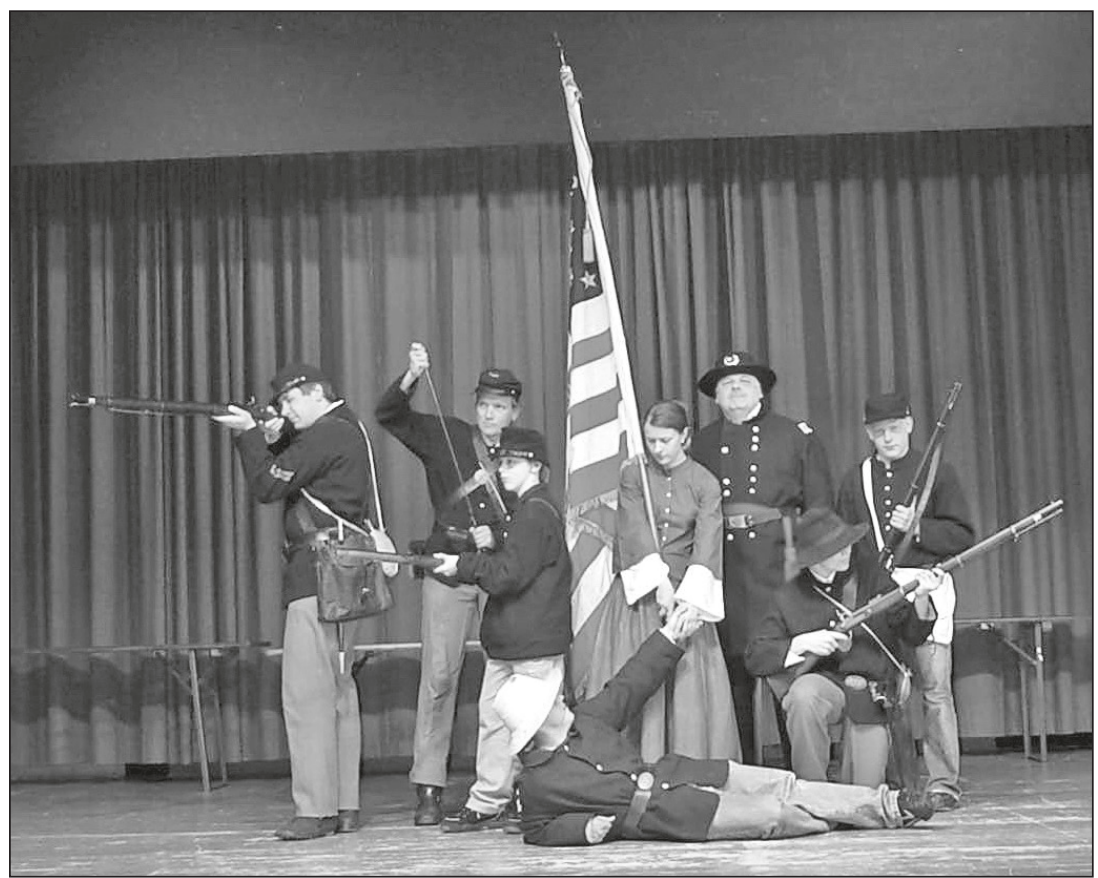

Fig. 6: Allegorical Tableau "Defense of the Republic" (ㄷ Wolfgang Hochbruck).

This is obviously not quite Brechtian, since it worked with identification rather than reflection to achieve the sudden insight, but capturing the effect in the discussion afterwards, and making the students not passive recipients of a message, but a part of an engaging and activating process, turned the performance into a consciousness-changing moment. Or so we hope.

\section{Conclusion}

Living history can work as an educational tool above and beyond its entertainment value. Especially where there is no memorial space for the events - no museum, no monuments, not even historic sites, as in the case of the Germans fighting in the American Civil War - reenactment formats adapted to the conditions of school and classroom can provide alternatives. The only precondition being that the fact that any and all forms of living history theater constitute forms of intentional historiography is acknowledged by performers, dramaturgy, and directors, 
and duly reflected as programs are outlined, developed, and performed. ${ }^{25}$ Living history programs in museums work through the congruency of site, costume, and activity. Staying "in character" should not be used extensively - at the most, a mixture of presentation "as if" and "about" will be effective.

There is ultimately no way beyond the ironic distance, even though participants and visitors might think there is, and talk about it. The famous "period rush" or "history flash" that some reenactors crave is a curious phenomenon, but ultimately a moment of re-cognition which relates to the original cognition like the reenacted battle to the original one - ironically, and in all likelihood triggered by previous (filmic) viewing experiences.

In the classroom, bringing in history in the form of a costumed interpreter can have the same effect - momentous immersion balanced off against the distanced position of the information resource. The insights and the historical comprehension competencies are left for the visitors and the students to work out for themselves in either situation. This, in turn, is what learning is all about.

\section{Cited Works}

Anderson, Jay. "Living History: Simulating Everyday Life in Living Museums." American Quarterly 34 (1982): 290-306.

Archambault, Alan. "Reflections on Civil War Reenacting." Camp Chase Gazette 21.5 (1994): 34-35.

Arnold, Volker. "Laudatio zur Verleihung des 5. Deutschen Archäologiepreises der DGUF an Harm Paulsen." (laudatory speech given at 7. Deutscher Archäologiekongress, 3-7 October 2011, Bremen).

Brand-Schwarz, Ullrich, Martin Klöffler, and Kristian Körver. "Geschichte - Historische Interpretation. Ein Erfahrungsbericht," in Living History in Freilichtmuseen: Neue Wege der Geschichtsvermittlung, ed. by Heike Duisberg. (Rosengarten-Ehestorf: Schriften des Freilichtmuseums am Kiekeberg, 2008), 60-78.

Brownawell, Eva Maria. Die Amerikaner und ihr Krieg: Analyse der Jahrhundertfeier des Civil War in den Vereinigten Staaten von Amerika 1961-1965. Stuttgart: Metzler, 1978.

Carson, Cary. "Colonial Williamsburg and the Practice of Interpretive Planning in American History Museums." The Public Historian 20.3 (1998): 11-51.

Dehne, Brigitte. "Wie komme ich zum Rollenspiel? Ein Bericht aus der zweiten Ausbildungsphase." Geschichte Lernen 23 (1991): 92-95.

Duisberg, Heike. "Gelebte Geschichte 1804: Ein Türöffner in die Vergangenheit. Das Freilichtmuseum am Kiekeberg," in Living History in Freilichtmuseen: Neue Wege der Geschichtsvermittlung, edited by Heike Duisberg. (Rosengarten-Ehestorf: Schriften des Freilichtmuseums am Kiekeberg, 2008), 60-78.

Faber, Michael. "Living History - Lebendige Geschichte oder Geschichte (er)leben?: Möglichkeiten, Methoden und Grenzen am Beispiel des Rheinischen Freilichtmuseums Kommern," in Living His-

25 Wolfgang Hochbruck. "Geschichte dramatisch nachbessern? Wissenschaftlicher Anspruch und Performativität im Museumstheater," in Vermittlung von Vergangenheit. Gelebte Geschichte als Dialog von Wissenschaft, Darstellung und Rezeption, ed. by Mitja Horlemann and Tobias Espinosa (Weinstadt: Bernard Albert Greiner, 2011), 77-87. 
tory im Museum: Möglichkeiten und Grenzen einer populären Vermittlungsform, ed. by Jan Carstensen, Uwe Meiners, and Ruth-E. Mohrmann (Münster: Waxmann, 2008), 117-133.

Handler, Richard. "Overpowered by Realism: Living History and the Simulation of the Past." Journal of American Folklore 100 (1987): 337-341.

Handler, Richard, and Eric Gable. The New History in an Old Museum. Creating the Past at Colonial Williamsburg. Durham: Duke UP, 1997.

Handler, Richard, Eric Gable and Anna Lawson. "On the Uses of Relativism: Fact, Conjecture, and Black and White Histories at Colonial Williamsburg." American Ethnologist 19.4 (1992): 791-805.

Handler, Richard, Eric Gable. "The Authority of Documents at Some American History Museums." The Journal of American History 81.1 (1994): 119-136.

Hank, Elisabeth. "Spiel im Geschichtsunterricht." Geschichte in Wissenschaft und Unterricht 42.4 (1991): 355-368.

Hochbruck, Wolfgang. “The Minden Reenactor Awards.” Insights Europe 16.1 (2015): 31-35.

Hochbruck, Wolfgang. "Chronosyndrom Light: Mittelalter als Projektions- und Rückzugsraum," in Das Mittelalter zwischen Vorstellung und Wirklichkeit. Probleme, Perspektiven und Anstöße für die Unterrichtspraxis, ed. by Thomas Martin Buck and Nicola Brauch (Münster: Waxmann, 2011), 217-233.

Hochbruck, Wolfgang. "Geschichte dramatisch nachbessern? Wissenschaftlicher Anspruch und Performativität im Museumstheater," in Vermittlung von Vergangenheit. Gelebte Geschichte als Dialog von Wissenschaft, Darstellung und Rezeption, ed. by Mitja Horlemann and Tobias Espinosa (Weinstadt: Bernard Albert Greiner, 2011), 77-87.

Hochbruck, Wolfgang. "Reenactment: Freilufttheater und Gedenkort," in Theater als Zeitmaschine. Zur performativen Praxis des Reenactments. Theater- und kulturwissenschaftliche Perspektiven, ed. by Ulf Otto and Jens Roselt (Bochum: transcript, 2012), 189-211

Hofmann, Birgit. "Distinguishing Forms of Historical Presentation at Civil War Re-enactments." Paper presented at the $1^{\text {st }}$ Annual EUCOR Trinational Masters Conference, Freiburg, December 10, 2005.

Hofmann, Birgit. "Forms of Historical Presentations at Reenactments." Wissenschaftliche Arbeit für das Lehramt an Gymnasien, Albert-Ludwigs-Universität Freiburg, 2006.

Hohmann, Franz. Kurze Szenen und Rollenspiele für den Geschichtsunterricht. Bamberg: C.C. Buchner, 2008.

Jones, Tamara. "Living History of Undying Racism: Colonial Williamsburg 'Slave Auction' Draws Protest, Support.” African Diaspora Archaeology Newsletter. 1.3 (1994): 1-3.

Junkelmann, Marcus. Muli Mariani: Marsch in römischer Legionärsrüstung über die Alpen. Stuttgart: Schriften des Limesmuseums Aalen, 1985.

Junkelmann, Marcus. Die Legionen des Augustus: Der römische Soldat im archäologischen Experiment. Mainz: Zabern, 1986.

Magelssen, Scott. "Making History in the Second Person: Post-touristic Considerations for Living History Interpretation.” Theatre Journal 58.2 (2006): 291-312.

Magelssen, Scott. Living History Museums: Undoing History Through Performance. Lanham MD: Scarecrow, 2007.

Matthews, Christy C. "Twenty Years Interpreting African American History: A Colonial Williamsburg Revolution." History News 54.2 (1999): 6-11.

Meier, Klaus-Ulrich. "Rollenspiel," in Handbuch Methoden im Geschichtsunterricht. Ed. by Ulrich Mayer, Hans-Jürgen Pandel, and Gerhard Schneider (Schwalbach: Wochenschau, 2007), 325-341.

Meiners, Uwe. "Verlebendigungsstrategien im Freilichtmuseum: Gedanken über Chancen und Probleme populärer Vermittlungsversuche.” Living History im Museum: Möglichkeiten und Grenzen einer populären Vermittlungsform, edited by Jan Carstensen, Uwe Meiners, Ruth-E. Mohrmann, 161174. Münster: Waxmann, 2008. 
Middleswarth, Vicky. "History and Hardtack: A Museum Workshop Program for Kentucky Teachers." Journal of American Culture 12.2 (1989): 87-92.

Neu, Tim. "Vom Nachstellen zum Nacherleben: Vormoderne Ritualität im Geschichtsunterricht." In Echte Geschichte. Authentizitätsfiktionen in populären Ge-schichtskulturen, edited by Eva Ulrike Pirker, Mark Rüdiger, Christa Klein, Thorsten Leiendecker, Carolyn Oesterle, Miriam Sénécheau, Michiko Uike-Bormann, 61-73. Bielefeld: transcript, 2010.

Nohejl, Regine. "Ruhm dir auf ewig, Borodino! Der Vaterländische Krieg im Russland der Gegenwart." Osteuropa 63.1 (2013): 61-74.

Packard, Stephan. "The Inventibility of Other Audiences: Thoughts on the Popular Ideology of Fiction in Transnational Comic Books, on the Occasion of Captain Marvel \#1." IJOCA. International Journal of Comic Art 20.1 (2018): 65-81.

Ralling, Christophe. Thor Heyerdahl: Eventyret og Livsverket. Oslo: Gyldendal Norsk Forlag, 1989.

Schmidt, Wolfgang G. and Babette Steinkühler. "Schauspieler zeigen die Revolution 1848/49." In Inszenierte Geschichte(n), ed. by Badisches Landesmuseum, Andrea Altenburg (Baden-Baden: Nomos, 1999), 67-83.

Stupp, Jason. "Slavery and the Theatre of History: Ritual Performance on the Auction Block." Theatre Journal 63.1 (2011): 61-84.

Taylor, Julie A. "Teaching African American History Through Museum Theatre." The Councilor: A Journal of the Social Studies 72.1 (2011): 1-11.

Teunissen, Martine. Representations of the Past in Public Spheres. Experiencing the Past: The Reconstruction and Recration of History at Colonial Williamsburg. Oegstgeest: Beleef Het Verleden, 2016.

Tilden, Freeman. Interpreting Our Heritage. Chapel Hill: University of Northern Carolina Press, 1977. 